\title{
Public Spaces and Conflict Transformation: From Mostar's Old Bridge to Its United World College
}

\author{
Joan Davison ${ }^{1}$ \\ Rollins College, Winter Park, FL, USA \\ Jesenko Tešan \\ Association of Societies in Transition, Zurich, Switzerland \\ The European Graduate School
}

\begin{abstract}
The purpose of this analysis is to offer a complementary approach to top-down ethnic conflict resolution which depends upon international organizations, peace treaties, laws, and political elites. While legal and institutional approaches can possess merit, they neglect the necessity of engaging people and rebuilding community. Further, citizens can perceive a top-down approach as coercive. This paper focuses upon an alternative approach of transformation through the construction of post-war public spaces which create places for interaction and sociability, and thereby possess healing power. We adopt the philosophy of architect Lebbeus Woods, who offered specific principles for the post-war reconstruction of Sarajevo. These guidelines included an acknowledgement of the damage and destruction, but also the necessity of community participation in rebuilding. We also accept the contentions of Keller Easterling who identified the potential coerciveness of 'extrastatecraft', that is structures imposed upon a community from above by the state, or from outside by international organizations. The specific focus of this research is upon Bosnia and Herzegovina, where the work of international organizations and national political leaders ended the military conflict in 1995, but still fails to reconcile the three ethnic groups to a shared future. The method is rooted in comparative political anthropology, which entails an evaluation of processes, agency, and structures, as well as an account for the emotional aspects of identity and politics. Interviews regarding conflict and reconstruction, and ethnographic observations of public spaces are employed. The work concludes that the contributions of the United World College - Mostar contrasts to the relative failure of the reconstruction of the Old Mostar Bridge partially are due to the emphasis of the former on community engagement and inclusion. The results admit the difficulty of post-conflict transformation in ethnically divided systems, but contend that both the process and outcome of community engagement in the reconstruction of public spaces facilitates reconciliation and democratization.
\end{abstract}

Keywords: Bosnia and Herzegovina, conflict transformation, extrastatecraft, heterarchy, post-war reconstruction.

\footnotetext{
${ }^{1}$ Correspondent Author E-Mail: jdavison@ rollins.edu
} 
Much of the democratization research of post-communist systems are categorized under 'transitology.' Transitology examines the various monumental changes that generally occur in most ex-communist, and more broadly ex-authoritarian, regimes in the process of democratizing. The subfield seeks to identify variables which facilitate successful consolidation of democracy as well as the causes of failed transition. Yet the initial academic emphasis upon parsimony arguably complicated the practical application to real cases (Blokker, 2005). Indeed, the early focus upon one dimension, the political - legislative power, elections, and parties - neglected potentially crucial aspects of democratization (Gans-Morse, 2004). Mohamedou and Sisk (2017) respond to these concerns with a broadened focus which includes analyses of the roles of legitimacy, culture, and economics.

Another inadequacy of early research arises from the robust finding that successful transitions occur most easily in homogeneous societies. The conclusion led to a certain level of futility, however, regarding transitions in multi-ethnic and multi-cultural societies; the typical solution was to create power-sharing governments which allowed party elites to represent their ethnic group, thereby diminishing input from average citizens. The complication of democratization in multi-ethnic systems further deepens if the society is transitioning both from authoritarianism and conflict, as is the case in many successor states associated with the former Yugoslavia. In Bosnia and Herzegovina (B\&H) the Dayton Peace Accords' (DPA) carefully crafted constitutional efforts at power-sharing failed because they provide vetoes for each ethnic group, leading to stalemate (Lippman, 2019; Norris, 2008). Moreover, the political leaders of B\&H's ethnoreligious political parties engaged in conflict entrepreneurship to maintain voter loyalty based upon the fanned fear of other ethnic groups (Belloni \& Deane, 2005; Crocker, 2007; Maksić, 2017; Piacentini, 2018; Sarajlić, 2010; Tešan, 2017). Ethnic leaders also practiced patronage, corruption, and nepotism which stifled good democratic government (Kapidžić, 2020; Lippman, 2019; Mujanović, 2018; Mujkić \& Hulsey 2010; Milan, 2019). Given the persistence of post-conflict interethnic tension in $\mathrm{B} \& \mathrm{H}$, it seems additional mechanisms of resolution beyond political accords and constitutional requirements are necessary to facilitate conflict transformation and democratic transition.

One overlooked variable related to transition is the development of public spaces, and their impacts on beliefs, identities, and social relationships (Carabelli, 2018; Easterling, 2014; Woods, 1993, 2011). The aim of this paper is to examine the stalled transition in B\&H through a focus on design, space, and place, particularly, but not exclusively, in Mostar. The general objective is to consider the use of public space in $\mathrm{B} \& \mathrm{H}$ as a vehicle for conflict transformation among seemingly hostile ethnicities and incompatible cultures. The analysis of the design of space as agent of transition, stands in contrast to already identified and tried instruments of constitutional design. In the case of B\&H, the power-sharing system the DPA designed to facilitate inter-ethnic cooperation has not succeeded, but instead locked individuals into exclusive identities and cultures (Lippman, 2019; Norris, 2008). The consequence is that individuals and communities are denied the possibility to transition to a peacetime, democratic system (Lippman 2019; Szakolczai, 2009, 2017).

This research acknowledges that debates exist regarding the nature of ethnicity and nationalism in $\mathrm{B} \& \mathrm{H}$, whether primordial or modern. Yet the research assumes that the various current exclusive, ultranationalist identities were constructed, or reconstructed, beginning in the late 1980s as Yugoslavia fragmented. Individuals of diverse cultural and religious traditions lived in the region for centuries dating to the Byzantine Empire. Periods of tension existed, most recently during World War II as Serbs and Croats supported opposing powers. Yet, the emphasis is upon the fact that after World War II, people coexisted and even intermarried, children attending school 
together and workers employed together. Some individuals simultaneously held multiple identities, for example as Muslim and Yugoslavian. The history of cosmopolitanism in Sarajevo is testament to this contention. Indeed, the 1991 Yugoslavian census did not even offer categories of Bosnian or Bosniak.

Thus, a shift away from the political solution of power-sharing, which presupposes the intractability of ethnic division, intends not merely to underscore the non-democratic state structures which reinforce prevailing differences, but also to focus upon the agency of design in conflict transformation. When heterarchy rather than hierarchy characterizes the construction of public spaces, the community is engaged in the process of the development, creating an initial forum for active citizenship and group interaction despite their differences (Carabelli 2018; Mihaylov, 2020; Pobric \& Robinson, 2019; Wollentz, 2017). Such a process might lead to shared purpose, and even shared identities. Moreover, the outcome, the specific design of the public space, can offer a place for subsequent interaction and sociability.

\section{Literature Review}

\section{The Construction of Identity in Bosnia and Herzegovina}

As noted, this analysis rejects the contention that ethnicity and nationalism are primordial. Rather, it embraces Anderson's (1983/2006) broadly accepted view of nations as imaginary and nationalism as constructed and contested. This is not to deny that pre-1990 B\&H possessed a multicultural, multi-religious character, but rather to emphasize that identities were not tribal, exclusive nor oppositional (Todorova, 1997). Rather identities are fluid, and multiple identities can be compatible.

Indeed, Raif Dizdarević, who served as the last Chair of the Collective Presidency of Yugoslavia prior to its dissolution in 1989, attributed the development of nationalist extremism to elites jockeying after Tito's death; he specifically mentioned the role of Milosević (Tešan \& Davison, 2020). Andjelic (2003) concurs, highlighting that in 1980 B\&H still lacked ethnic associations among its proliferating civil society organizations. In the late 1980s and early 1990s a burgeoning democratic civic nationalism developed in contrast to ethnic nationalism. A notable example of such civic nationalism was Sarajevo's 1992 April Spring for democracy which attracted B\&H citizens of all economic, ethnic, religious, and social backgrounds (Tešan \& Davison, 2020).

Yet, leaders of all ethnic groups, particularly Milosević, Šešelj, Izetbegović, Karadžić, and Tudjman, played upon the emotions and insecurities of people during the transition from socialism, blaming other ethnicities, and promising solutions based upon nationalistic policies (Omaljev, 2016; Tešan \& Davison, 2020). As Milan Kučan, the first President of Slovenia from 1991 to 2002 recently emphasized, the war actualized the nationalist claims as ethnic groups became enemies (Telesković, 2020). The DPA which concluded the war and established the constitutional system in $\mathrm{B} \& \mathrm{H}$ then recognized and reinforced the ethnic identities and related rights of Bosnians, Croats, and Serbs at the expense of unrecognized groups, labelled in the DPA as "others". These others included Jews, Roma, and individuals of mixed marriages (Halilovic-Pastuovic, 2020; Lippman, 2019; Norris, 2008; Tešan, 2017). Under such polarized circumstances, conflict transformation does not progress (Kapidžić, 2020; Maksić, 2017; Mujanović, 2018, Milan, 2019; Piacentini, 2018).

Substantial research exists, however, which demonstrates that citizens of B\&H are challenging the monopoly of ethnic nationalism (Lippman, 2019; Omaljev, 2016; Pobric \& 
Robinson, 2019) and engaging in civic activism based upon other shared identities. Mujanović (2018), Kurtović (2018), Milan (2019), and Lai (2020) each have studied the work of social movements and civil society against state and corporate decisions in B\&H. Belyaeva (2017) analyzes how protests against economic policies broadened to campaigns against government corruption. Carabelli (2018) examines the role of artists with respect to both art shows and youth art programs. Milan (2019) discusses a range of movements including 'the Park is Ours', 'the Baby Revolution', and the 'Social Uprising.' Each attracted citizens from all ethnic and religious groups who were mobilized due to socio-economic concerns. These movements challenged the perceived corruption and incompetence of the ethnic based governments. Swimelar (2020) focuses upon the growing strength of LGBT identity, as well as the weakening of the specifically ethnonationalist response. While objections to the Sarajevo Queer Festival of 2008 were founded in ethnic identity arguments, opposition to the Pride Parade of 2019 shifted to a focus on family values. Notably both the LGBT activists and their opposition recognized benefits to organizing citizens from all ethnic backgrounds. Likewise, Mihaylov (2020) notes increasing international leverage on leaders of ethnic groups to dialogue and cooperate.

Accordingly, the research recognizes that groups which transcend ethnic divisions are developing. Despite the impediments of the existing political structure, these movements offer opportunities for transition. In mobilizing individuals and groups, civil society not only facilitates participation, socialization, and dialogue, but also creates opportunities for post-ethnic, inclusive identities, and models of citizenship (Milan, 2017). Kurtović (2018) contends that even if these movements fail to achieve their specific objectives, they nonetheless emphasize new groups and cleavages in society which challenge the war-time and immediate post-war notion that ethnic divisions are permanent, and necessarily dominate politics and governance. Our research concurs. Yet, its specific focus, unlike most research which examines the political variables, constitutional experiments, and cultural animosities, is upon the role of design and architecture. Nevertheless, the analysis acknowledges that political actors often influence or determine the character of design and infrastructure, and hence the qualities and benefits of public places.

\section{The Construction of Space}

Easterling (2021) believes a state's 'infrastructure' includes the design process and architectural product. These powerful forces shape not just public space, but human beliefs, norms, and relationships within that space. Just as a state's control of the internet affects citizens' ability to receive information and make connections, so too, a state's use and design of public spaces can constrain or liberate. The cemetery, bridge, park, community center, and classroom assume agency. Each serves as a 'medium' that designs or constructs space and affects the attitudes and behavior within space (Easterling, 2021). The potential significance might be realized in the consideration of post-war monuments to heroes and victims, especially in divided societies such as B\&H where the facts of the conflict are disputed. Monuments which memorialize certain events or individuals influence beliefs about the war, and accordingly serves as a 'technology' (Horvath, 2021) or tool for conflict resolution (or perpetuation) not dissimilar to peace treaties and constitutions such as the DPA. Aquilué and Roca (2016) examine this dynamic in the rebuilding of Sarajevo and the neighboring Serbian enclave of East Sarajevo. Kappler (2017) and Morrison (2016) analyze the disputes regarding what should be memorialized (and alternatively forgotten) in post-war Sarajevo. Pobric and Robinson (2019) focus upon the relative power of government and business compared to social groups in making decisions about reconstruction. Comparable research exists for Mostar (Carabelli, 2018; Mihaylov, 2020; Wollentz 2017, 2019). 
The notion of who controls decisions about the use of space and creation of public places relates to Easterling's (2014) discussion of 'extrastatecraft' as "the often-undisclosed activities outside of, in addition to, and sometimes even in partnership with statecraft" (p. 15). Extrastatecraft is critical as the means through which states, as well as international organizations and powerful external and domestic economic actors, transform environments and systems for their own benefit to realize political power and financial profit. States and external actors can craft infrastructure space to manipulate social attitudes and relations in ways which reinforce the interests of authoritarian governments and corporate interests (Easterling 2014, 2021).

Easterling's Medium Design (2021) contends that the medium relates to the potential of extrastatecraft to reinforce the power of dominant elites. Aquilué and Roca (2016) examine how the Serbian leadership within B\&H constructed East Sarajevo with the objective of maintaining ethnic separation and purity. Pobric and Robinson (2019) identify not only the power of local government but also international finance and tourism in the reconstruction and gentrification of post-war Sarajevo, one outcome of which is to make housing unaffordable for the young, workers, and new arrivals. Wollentz (2017) focuses upon Mostar and the failure of local leaders to be attentive to pre-war memories of tolerance and integration. The question of whose heritage should prevail becomes especially important when one considers the development of UNESCO sites such as Mostar's Old Bridge (Forde, 2016). Here international experts might work with national or local political leaders, but neglect civic groups (Brumann, 2018; Hill 2018; Silverman 2020).

Yet, the opportunity to design space also can promote activism, challenge authoritarianism, and overcome political deadlocks (Easterling, 2021). Milan (2019) illustrates this dynamic with the case of Banja Luka and the 'Park is Ours' movement. A broad coalition of community groups mobilized to stop political and economic interests from building a mall on popular parkland. Other researchers also have studied the controversies regarding the design of public spaces, and the potential for design to facilitate healing (Kappler, 2017; Morrison, 2016; Pobric and Robinson 2019; Wollentz 2017, 2019). Within liminal regions where conflict transformation has stalled, the power of the design process and outcome offers the potential for representatives of hostile community groups to overcome misconceptions and perhaps find common cause (Carabelli, 2018; Mihaylov, 2020).

Consistent with Easterling (2021) this research assumes that design in a post-conflict space of reconstruction is not merely the creation of a place, but rather represents reproduction of an idea or thought. In a post-conflict environment, space, time, architecture, monuments, doors, bridges, and windows may become the agents of failed or negative transition, depending upon how infrastructure and architecture convey information, manipulate belief, affect relationships, and invite friendship. Consider the red doors of the Basque country and the painted curbs of Northern Ireland. Designs might facilitate or hinder conflict transition. If they tap into existing views of the war's origin or advance polarized beliefs, they might harden wartime animosities into the postconflict setting thereby derailing efforts at ethnic cooperation. Indeed, in $\mathrm{B} \& \mathrm{H}$, the war about the war continues: was it a civil or international war; a war of independence or aggression; did a genocide occur, and if so who committed it? Which victims and heroes should be commemorated, especially in public spaces? Thus, infrastructure, architecture, and place can support either conflict or its transition.

The late, renowned architect Lebbeus Woods $(1993,2011)$ advocated for an appreciation of the power and responsibility of architecture for post-conflict and divided societies, including Sarajevo. Woods (2011) contended architects as designers should respect difference, promote tolerance, and facilitate dialogue. His work on power, war, architecture, and reconstruction argued 
that historically and culturally significant buildings should be restored to their pre-war character to help people overcome trauma through the familiar and cherished (Woods, 1993). He also argued that local architects should spearhead design, acknowledging that society's pre-war normal was destroyed and could not be exactly replicated without denying the inhabitants' experiences of war. Consequently, ordinary homes and offices must establish a new normal based on not only the past normal, but also the reality of conflict, destruction, and transformation. Most significantly, he contended that community groups would negotiate the reconstruction.

Following Woods (2001), architecture should honor difference and heterogeneity. Through the tolerance of individuality, the notion that difference is exceptional will be eliminated, and so too the perception of the 'other', while establishing a foundation for dialogue, sociability, and collaboration. Woods $(1992,2001)$ believed heterarchy would then characterize relationships. Individuals would possess the opportunity (and right) to control their interactions and ultimately community development. As such, heterarchy contrasts with extrastatecraft. Extrastatecraft hierarchically imposes the objectives of political elites, corporate interests, foreign investors, and international organizations upon citizens. Easterling (2014) asserts "[c]ontemporary infrastructure space is the secret weapon of the most powerful people in the world precisely because it orchestrates activities that can remain unstated but are nevertheless consequential" (p. 15). Heterarchy fosters tolerance, dialogue, and collaboration in communities (Woods, 1992).

From such a perspective, the process and product of design are critical, particularly during post-conflict transitions because construction, especially of public buildings, art, monuments, and spaces, affect views of and relations among ethnic groups, whether as friends, enemies, or others. In the $\mathrm{B} \& \mathrm{H}$ post-war liminality of ethnic tension and elite corruption, design which fosters community engagement offers the possibility of conflict transformation through heterarchy.

\section{Research Method}

Political anthropology generally employs fieldwork to study problems of politics, recognizing politics operates within varied social, economic, and cultural settings. The subfield allows for a deeper analysis of a case which does not conform with the expectations of theory, such as $\mathrm{B} \& \mathrm{H}$ with respect to transitology or power-sharing. Political anthropology highlights that seeming exceptions can appear if political scientists emphasize the rational and neglect the emotional component of human actions (Horvath \& Szakolczai, 2018; van Gennep, 1960/2019). Concepts of liminality highlight the irrational moments, such as war, which occur. Attention to irrational elements aids an understanding of the schismatic divisions which persist even when rational behavior might advance individual and collective well-being (Szakolczai, 2009, 2017; Thomassen, 2008, 2014)

This research looks at the case of $\mathrm{B} \& \mathrm{H}$, and within that case compares the design and reconstruction of the Old Mostar Bridge with the United World College - Mostar's (UWC - M) use of space. The notion of design includes both process and structure, who was included in the construction decisions and how the outcome affects beliefs and relationships. This analysis juxtaposes the space the Old Mostar Bridge occupies with the place UWC-M offers, the agency of each design, and the experience of their subjects.

The research employed ethnographic observations of individuals on the new Old Bridge. Some individuals on the Old Bridge engaged us in discussions. Semi-structured interviews were conducted with administrators at UWC - M in 2019. These observations and interviews focused on the design of the school and bridge. The mission statements of UWC $-\mathrm{M}$ also were examined. 
Information from previous studies also informed the research. Most notable were three days of semi-structured interview with Raif Dizdarević in 2017. Additionally, previous meetings with leaders of various $\mathrm{B} \& \mathrm{H}$ civil society groups and international governmental and non-governmental organizations groups created context for understanding. These organizations were located primarily in Sarajevo and Mostar, but also East Sarajevo, Banja Luka, Srebrenica, and Novi Sad. Finally, prior research in the Archives of the B\&H parliament informed the research, specifically with understanding the interests of ethnic leaders and political elites based upon the translation of tapes from sessions.

\section{Discussion}

\section{Mostar's Bridge: The Agency of Architecture}

Design, architecture, and space possess the capability to engage and transform post-war cultures and societies, not merely restoring the old normal but creating, as Woods (1993) suggests, a new normal. The question is whether the medium design successfully moves individuals and society from a war context to conflict transformation, in the case of B\&H perhaps moving them beyond the mere mechanisms of an elite power-sharing to real tolerance, cooperation, and democracy. Notable in this case, is that cross-cultural interactions and ethnic tolerance did characterize the pre-war normal. To this extent, real, not merely imaginary, places offer some guidance. Yet, the war and atrocities did occur, Sarajevo suffered siege, and the Old Mostar Bridge was destroyed. Therefore, it is not sufficient to replicate the pre-war places; the war-time experiences of the people require consideration if design is to be relevant. Transition necessarily entails an acknowledgement of local sentiment, struggles, differences, and needs, as well as the locals' desire to craft their future.

A specific question concerns how space and design alter the beliefs of individuals trapped in liminality, and consequently how infrastructure and place can affect relationships and conflict resolution. Mostar literally means bridge keepers, and refers to the guardians of the Old Bridge which was constructed in the $16^{\text {th }}$ century to connect the two sides of the multi-cultural city where Catholics, Jews, and Muslims lived. In 1993, during the war, the bridge was destroyed. After the war, external actors associated with UNESCO and the World Bank constructed a new Old Bridge for political and economic purposes. They well-intended the new bridge to resurrect the historic bridge's emphasis on community and sociability across cultures, and also to revitalize tourism. Yet, many people in Mostar view the new bridge's design and construction as imperial and counterfeit. They experience the process and outcome of design to highlight the structure as an imitation which minimizes the local hurt and division, and pretends the war did not occur and the bridge was not destroyed (Forde, 2016; Greiff \& Greiff, 2014). The bridge, but not sociability and interaction were resurrected. Authoritative extrastatecraft (of local and international officials) created a place for tourists and cheap souvenir shops, but did not overcome deadlocked ethnic groups or divided society. The intended return to the old normal proved impossible, and a new normal remains elusive because neither Croatians nor Bosnians (an arguably constructed wartime category) accept this new Old Bridge as belonging to them. In fact, the now permanent new bridge represents how a disregard for conflict resolution - in politics, society, or architecture - can contribute to a permanent liminality, that is a frozen conflict in which the war has ended, but real peace is absent because external actors are constructing solutions without the affected individuals' engagement in moving to a post-war resolution. 
The power of infrastructure and architecture to influence cultural norms and beliefs is evident in the exploration of the meaning and voice of the original Old Bridge in contrast to the new Old Bridge. (It is notable that this is the distinction which local inhabitants have coined: the new Old Bridge versus the old Old Bridge.) Missing from the new Mostar bridge is the care the people felt for the Old Bridge as a source of cultural and civic identity and pride. Indeed, the original bridge which spanned the river for more than four centuries was tenderly referred to as the old Old Bridge because old people of Mostar cared for it. The Old Bridge served as a place of connection and sociability among old people, but also between people and the bridge itself. The 'restored' bridge is far too crowded with global tourists for the local old people to meet, share coffee, and care for one another and the bridge. A Croatian shopkeeper explained that bridges in Mostar no longer serve as points of connection, but rather mark division. When he must cross to the Bosnian side of the river he avoids the new Old Bridge because it was rebuilt without addressing underlying ethnic tensions. One elderly resident, a Muslim woman whose Serbian husband died in the war said, "the new bridge is wider to accommodate more people, but no longer accommodates us. If my husband were alive, it could not accommodate us together." Is accommodating more people positive, perhaps affording the opportunity to include greater diversity? Or does the accommodation of more people replace the depth of feeling for the bridge with the shallow commercialism of capitalism and the dog-eat-dog competition among kebab restaurants and gelato stands? Easterling (2014) warns about extrastatecraft's preference for consumerism, capitalism, and tourism. Pobric and Robinson (2019) raise this point regarding Sarajevo's Old City.

Prince Charles highlighted the desirability of local connection and traditions of design in a speech attacking modern British architecture as "a monstrous carbuncle on the face of a much loved and elegant friend" (Slessor, 2019, para. 1U). Globally inspired and technologically advanced trends as concerned Prince Charles, often appear within transitory regions such as B\&H. Examples of carbuncles in B\&H include the proliferation of Saudi financed and inspired mosques throughout the region. These new constructions displace the traditional Ottoman inspired, indigenous B\&H mosques which blended with neighboring small shops, Catholic and Orthodox churches, and Jewish synagogues. So too, the glass and steel shopping malls juxtaposed to the historic old towns of B\&H appear as alien monstrosities. Ironically then, in 2004, Prince Charles dedicated the new Old Bridge in Mostar, failing to understand how local people might receive it as a "carbuncle." The new Old Bridge in Mostar represents a break with the memories of the people. The reconstruction attempts to stage a multi-cultural city while masking the violence of the war and the authoritativeness of extrastatecraft.

Within the post-conflict region of $\mathrm{B} \& \mathrm{H}$, and specifically Mostar and the bridge, the control and demand of compliance from the state and its technologies alienates individuals from self and society. Post-conflict people and spaces experience liminality, that is the violent war is over but ethnic tensions persist. While liminal spaces can serve as places of passage, they also can serve as spaces of intransigence and division if inhabitants lack the means to move beyond conflict. The new Old Bridge, as a design of international actors, serves as an example of extrastatecraft's control. In this situation, Easterling's medium design, which focuses upon the landscape and grounding of the infrastructure, is indeed beneficial for conceptualizing the problems of divided societies and their conflict or reconciliation. Liminal spaces serve as media for technologies of the extrastatecraft, which in turn can perpetuate the situation as a permanent liminality of division (Thomassen, 2012).

Nonetheless, the memory of the original Old Bridge witnesses to the possibility of architecture promoting sociability. The Old Bridge (the old Old Bridge to the local community) allowed the people and societies to retain agency. Rather than treating individuals, ethnicities, and 
societies as separate, the old Old Bridge served as the platform and connection which offered the possibility of dialogue, engagement, and shared purpose. The new bridge fails in this regard. The structure imitates the bridge which stood for four centuries, but the atmosphere is akin to Disney's Epcot Center World Showcase which fabricates happy nations and artificial cultures for tourists. The reconstructed Mostar bridge attracts visitors who snap a photograph and reboard their busses. The bridge did not arise from the local sentiment and as such is not a point of interaction and healing. The construction of the new bridge fails to facilitate transition; it does not offer a place for the diverse peoples of $\mathrm{B} \& \mathrm{H}$ to communicate. Local residents now claim they must search for spaces of relaxation away from the once beloved bridge.

The Croatian destruction of the old bridge was the symbolic climax of the destruction of the old normal of Mostar. A new bridge cannot restore that normal. A new normal which addresses the conflict and transformation might begin the process of reconciliation if the community engages in the design. If local people accept this possibility, then they might create the environment which allows movement from conflict to post-conflict, from liminality to normality. As Woods (1993) contends regarding the involvement of local architects, local individuals must retain their agency, unlike the new extrastatecraft bridge which embodies control. The point then is that space and its design can present a place for sociability and community, as did the old Old Bridge. Within B\&H and Mostar, places exist that offer agency to diverse individuals. Following Woods (1992, 2001), architecture should honor such heterogeneity and heterarchy, meeting the needs of all individuals, and thereby eliminating the notion of the other, while establishing a foundation for dialogue, tolerance, and collaboration.

\section{Heterarchy and Active Citizenship}

Easterling (2014) regrets that much of contemporary infrastructure space responds to capitalist interests and promotes consumerism. Was that the intent of extrastatecraft's new bridge in Mostar - to attract tourists for the financial benefit of the state and private economic interests? Within $\mathrm{B} \& \mathrm{H}$, are there spaces where design focuses upon the advance of sociability, reconciliation, citizenship, and an active democratic polity which possesses agency? Various research suggests citizens must mobilize to create and retain such places (Carabelli, 2018; Milan, 2019; Morrison, 2016; Pobric \& Robinson, 2019).

After the 2011 massacre in Norway, street artists initiated the development of spaces to advance tolerance and healing (Tellidis \& Glomm, 2019). So too, the peace walls of Belfast sharply contrast with partisan hate-filled murals - the former convey shared values while the latter espouse difference. When artists, architects, and designers assume the role of social gadflies apart from extrastatecraft, they often offer agency to the observers for a new consociationalism and new identities, hence understandings. They present the place for individuals to reconsider the nature of the other and the costs of divided societies, with the possibility to affect liminality and conflict resolution. The arts community in Mostar fills such a liminal void (Carabelli, 2018). Likewise, the annual Sarajevo Film Festival represents a public place in which diverse individual and multiple collective identities are welcome. The Festival with a commitment to tolerance and peace, is an experience of food, drink, music, and art to which people from throughout B\&H flock with the objective of remembering the pre-war and war-time pasts in order to mold the post-war future. The presence of food and drink in outdoor open spaces provides sunshine and fresh air as intentional contexts for thoughtfulness and community. 
Thus, expanding Easterling's (2014) argument into the field of conflict resolution presents an "alternative aesthetic and political repertoire" (p. 214) for the understanding of just peace. Abandoning the DPA's elite-constructed B\&H 'peace' offers the possibility of non-state dissent from official "truths" and a possible canvas for the healing process. The state and economy can perpetuate injustice and violence through oppressive power including control of technologies. Nonstate, non-economic actors can represent a dissent from such control; artists and architects in particular depend upon free expression and so too their designs invite observers to assume agency in the interaction with the work and place as well as with other individuals who share the environment. This is the advantage of the Sarajevo Film Festival. Conversely with respect to the state, Easterling's (2014) statement on the outcome of binary stances is powerful: "David must kill Goliath" (p. 211). In the absence of conflict resolution, polarizing beliefs trap B\&H in the war-time mentality of one ethnic group against the other group. Thus, arises the necessity of offering heterarchy's tolerance and engagement as alternatives to extrastatecraft which focuses upon consumerism and competition. The former creates canvases and places for conflict transition and ethnic reconciliation.

To this point the analysis focused on extrastatecraft, artists, and architects. Arguably educators as employees of the state might assume either authoritarian or liberating roles especially in liminal times. To the extent hierarchical political or economic interests control educators, educators might be required to present certain perspectives (Basic et al., 2019; Emkic 2018; Tolomelli, 2015). Yet, educators, like artists and architects, often prize free speech and thought, and desire to share the liberating and humanizing nature of freedom with others, particularly young people who represent society's future investment. To the extent educators seek to give agency to students, the space of schools in post-conflict areas can be critical to students' ability to engage in dialogue. Related to heterarchy and engagement, consider whether desks are ordered in rows or circles, whether the educator stands apart on a platform or moves amidst the class, and whether the spaces become places of academic freedom.

Indeed, a specific problem for the B\&H post-conflict transition is the state's system of 'two schools under one roof,' a system which segregates children based upon ethnic identity. In its report, the Organization for Security and Cooperation in Europe Mission to B\&H (2018) stated “... through this segregation [they] teach them that there are inherent differences between them. In post-conflict $\mathrm{B} \& \mathrm{H}$, this increases mistrust among members of different national groups, impedes reconciliation and is a long-term threat to stability, security and economic prosperity" (p. 4). The state controls education and educational places, and as such influences the present and future of individual identities and ethnic relations. Teachers well might embrace particular ethnic views that impedes the success of peace education (Emkic, 2018). To this extent, private schools, although often criticized as refuges for the privileged, can serve as vehicles for transformation if they seek to promote cooperation and unity among people. Such is the focus of the United World College system which also provides all students with scholarships, ensuring a broad representation of economic and social groups.

\section{United World College-Mostar: A Place Constructed for Conflict Transformation}

The specific objective of UWC-M is worth highlighting: "Building bridges between people and cultures through inspiring, quality education" (UWC-M, 2016, Who we are section, para. 1). The emphasis on bridges is intentional. The point is to convey empathy both with the importance of the Old Bridge in Mostar, and more generally bridges as infrastructure for sociability. A bridge allows people to assume agency, cross-over, meet, and interact. UWC-M understands its role in 
educating individuals "...to learn and appreciate their differences, while promoting equality, tolerance, and critical thinking" (UWC-M, 2016, Who we are section, para. 3). Such values are consistent with heterarchy and community engagement. Further, UWC-M is the first institution in the United World College (UWC) system to focus upon post-conflict reconstruction. In this regard, it is notable that UWC-M chose to occupy space in the Gymnazia Mostar (a state school) as an invitation to individuals and societies, and most especially students outside UWC-M, to witness and participate in a place of reconciliation, tolerance, and equality.

Discussions with the administration at UWC-M revealed the selection of space was purposeful. First, the city of Mostar was the war-time 'No Man's Land,' the former front line where borders, identities, and beliefs were and are liminal. Yet, school administrators stressed the importance of Mostar's continuing diversity in an increasingly segregated B\&H. Mostar remains multi-ethnic although tensions persist between ethnic groups.

The location of UWC-M within the space of Gymnazia Mostar also is intentional, hoping to affect attitudes among state school officials and students within the building. The Gymnazia has one administration for the state's school, but shares two programs within one building. The public school operates on the first two floors of the building with Croatian students on one floor and Bosnian students on the other floor. The UWC-M operates on the third floor. The schools share a space, but each has created a very different place which support different values - one of homogenous, segregated societies - the two schools in one building - the other (in some ways the third) of heterogeneous, integrated community. Through some shared spaces and activities with the Gymnazia students, UWC-M hopes to introduce heterarchy. This stands in contrast to the hierarchical manner in which the Gymnazia was reconstructed under United Nations and European Union supervision with United States' funds. The Gymnazia, in the Croatian section of Mostar still stood in contrast to most schools on the Bosnian side which were destroyed.

Research indicates that superficial success has occurred; UWC-M's values have seeped into the Gymnazia, but the lasting impact among the Gymnazia students is less certain (Alic et al., 2018). Yet, UWC-M also intends to be among the public and a part of the society outside the school walls. UWC-M seeks to create a place where all students are comfortable and equal so that they might move beyond existing in the same classroom to a point of identifying as a single cohort with a common purpose.

The selection of the Gymnazia Mostar space for UWC-M also relates to the architecture of the school, a stunningly restored Austro-Hungarian building. The UWC-M administration notes it wants to reconstruct and renovate buildings to their pre-war architecture. Consistent with Woods, the sentiment is that destruction should be replaced, but with an acknowledgement of the pre-war and wartime cultures which provide a basis for the future. Administrators explain that individual UWC-M classrooms invite students to look out large windows and see both destroyed and reconstructed buildings as well as the beauty of the landscape and the possibilities of nature. Strung across the ceiling of the Spanish language classroom are national flags of the approximately 200 enrolled students, about 100 from $\mathrm{B} \& \mathrm{H}$, and 30 from Mostar. While this might suggest an unconscious acceptance of the power of states, the school sends the message of the equality and celebration of all nations. "UWC Mostar has become a part of Mostar's post-war identity..." (Alić et al., 2018, p. 66). The school's presence is notable across the city such that its activity and design has challenged the empty space of "no man's land," and prompted new dialogue which crosses the borders of ethnicities and cultures. 
Indeed, UWC-M does not merely operate within a building in Mostar. Rather, it attempts to influence the various ethnic groups through its presence throughout the city. UWC-M's student residences are intentionally spread throughout a variety of neighborhoods on both sides of the river to enable students to engage with the community. Students walk to classes, through the city streets, as representatives of tolerance. Likewise, UWC-M students engage in community activities - art shows, tutoring, global festivals - throughout the city. Teachers take students to public places for field trips and public parks for classes to make public spaces into places of tolerant diversity. Osler and Pandur (2019) stress the importance of UWC-M's community engagement and service learning. They find that community engagement is essential to the mission of the school to build bridges. While UWC-M's building and classroom matter, administrators acknowledge that it is the intentional use of public places which is transformative. Easterling asserts it is possible for private corporations to control public spaces. So too, UWC-M seeks to fill the void of no man's land's public spaces with a design of public places that promote conflict resolution through welcoming civic activities.

In fact, there is some evidence that students at UWC-M not only engage in Mostar, but also seek to take the tolerant and welcoming attitudes back home to their local communities throughout B\&H. Thus, we might conclude in accord with Easterling (2021) that to the extent that private entities can build or control public space, the possibility exists for these actors (agents from diverse segments of civil society) to design space conducive to the free development of each and all individuals and groups. UWC-M is filling in public spaces with alternative culturally sensitive, tolerant, and integrative perspectives; they are filling no man's land with a path for conflict resolution, and then transformation.

\section{Post Conflict B\&H}

Although the war in B\&H ended twenty-five years ago, much of the country's infrastructure still requires repair. The same is true of its communities and societies which appear collapsed, decaying, or unloved. The post-conflict cloud of liminality and apathy persists, and community developed architecture, art, and design might play a role in the healing processes. Van Gennep (1960/2019) described liminality as transitory experience, but some scholars who study modern stalled transitions emphasize the alternative possibility of psychopathic or schizophrenic societies in which irrational division ceaselessly persist (Horvath \& Szakokczai, 2018; Thomassen, 2008; Szakolczai, 2009). Space - bordered, divided, territorialized - can contribute to trauma, but space also can heal and be an agent of healing (Thomassen 2012). Thus, Woods contends that the architecture and design of post-war public spaces must embrace the scars of the past to serve as not merely a memorial but also an antidote. Scars across the B\&H landscapes and public places are the reminder of war-time damage, but so too emblematic of the healing and healed. Scars replace the festering wound, but remain to represent the experience of injury. B\&H certainly has witnessed debates regarding which scars to memorialize and which to heal. Disputes arose and continue regarding the Srebrenica cemetery and memorial, the bulldozing of Sarajevo's red roses, and the renovation of the Holiday Inn. In fact, roses at the most significant sites of sniper fire have been kept, but other red markers have been removed for road repairs necessary to improve transportation. Likewise, although at one-point bankrupt, The Holiday Inn was not razed and its iconic yellow exterior still highlights Sarajevo (Morrison, 2016). Yet, these were local decisions which evolved over time. This suggests why the Mostar Bridge should not have been replaced until the local people restored it. The wound, healing, and scar are part of the process of conflict transformation. 
Sarajevo city project, in particular the so called Marijin Dvor zone, was Woods' attempt to help design the lasting healing process. He envisioned transformation of the scarred city in which architecture and design would offer a powerful transformative tool. Space and design would undergird conflict resolution to the extent individuals and communities could find security in restored spaces which also restored normalcy; the reconstruction should tie to the past but also offer the comfort of the new (Woods, 1993). The emphasis is upon beginning from the end of the pre-war era rather than starting entirely anew in the present post-war. Use of damaged materials and buildings, is not only fiscally responsible, but also focuses upon the injuries and scars (perhaps akin to the work of truth and reconciliation committees) so that people and communities might liberate themselves from the grip of liminality which exists. Woods (2011) allowed in his proposal for the transformation of Sarajevo a certain flexibility. He conceived that architecture would not complete a transformation or reconstruction until human beings used the spaces and structures for their purposes, creating places and relationships. Woods (1993) did not wish people to forget the war-torn city, but to remember the conflict so that citizens possessed the option and agency to transform, to change from inflicting pain to nourishing well-being.

The struggle over conflict transformation in Mostar and Sarajevo, and throughout B\&H, continues. Outdoor art, concerts, and theatre are one vehicle through which private agents strive to involve the public in consideration of alternative memories of the past and visions of the future. Another private project under development is a skatepark for Sarajevo modelled after the Rwanda park designed for reintegration (Betonlandschaften, 2021). Such skateparks create safe meeting places for young people of all backgrounds. Skateboarders enjoy the opportunity to demonstrate their individual skills apart from any identifying ascriptive tags. The parks present the space, but the individual decides how to use the space for their tricks. Each skater constructs a personal place as they negotiate the skatepark space (Association for Societies in Transition, 2021). Parks then are locations in which the participants negotiate the rules regarding the time and method of use; parks serve as a participatory, democratic, inclusive, and potentially transformational places.

Frustration certainly exists about stalled post-conflict transitions. Various international organizations have invested substantially in conflict resolution in contested lands. The European Union, the Organization for Cooperation and Security in Europe, and their member states have worked in B\&H for 25 years. The power-sharing mechanisms of the DPA have not facilitated ethnic cooperation. Although other non-political mechanisms might work, one should not overlook the potential that the design of spaces and the messages of places hold for identities, beliefs, sociability, and transformation.

\section{Results}

The challenge of democratization in post-communist, post-conflict systems was the point of departure of this analysis. It was noted that multi-ethnic societies faced even greater impediments to transition than other formerly authoritarian states. Efforts to overcome ethnic tensions typically relied upon constitutional structures and legal frameworks which designed power-sharing systems. Yet in B\&H such a system failed to resolve mistrust, and in fact cemented tensions while also creating opportunities for elite corruption. The review of literature highlighted nationalistic leaders who used public spaces to further personal political and economic interests. International organizations, foreign finance, domestic corporations, and government officials designed spaces without the participation of citizens and civic groups. In the last decade, citizens 
have started to mobilize to control the use of space, for example wishing to maintain a park rather than build a mall.

The analysis focuses upon the possibility of design and architecture to influence identities and relationships and thus perhaps facilitate conflict transformation. Of course, not all groups seek transformation. Societal groups exist which advocate separation and secession. Yet, for healing, heterarchy seems essential. The significance of UWC-M is not only the design and architecture of the actual school but also how UWC-M interacts with people of all ethnic groups across the city, particularly in public places. As such this research contends that projects such as the Sarajevo Film Festival, Banja Luka park, and potential Sarajevo skate park are critical to healing and tolerance both because the designs originate in the community and the created places are open to sociability. This contrasts with the case of the new Old Bridge of Mostar. Its reconstruction illustrates the practice of extrastatecraft which hierarchically imposes design upon citizens in order to advance particular interests. While the story of the bridge's reconstruction as a symbol of renewed multiculturalism pleases tourists, local residents question the intent and value. They realize that the bridge cannot again serve to connect people unless people of all identities participate and collaborate in its building.

While other studies have discussed citizen engagement in the reconstruction of space in post-conflict $\mathrm{B} \& \mathrm{H}$, they have not used the frameworks which Woods and Easterling offer. To this extent, they have not directly contrasted the possibility of citizen involvement in the design of public space with the constitutional and legal mechanisms that transitology typically advocates for democratization. Post-war reconstruction is critical to transformation but not sufficient; conflict transformation also necessitates individual and civic group engagement in the creation of future places. Heterarchy's premium on tolerance and participation offers possibilities for both conflict transformation and democratization.

\section{Funding Details}

This work was supported by Rollins College under a Cornell Research Grant.

\section{References}

Alić, A., Cerić, H., \& Habibović, S. (2018). The rulers of "No Man's Land" - Study of cultural contact and social impact of the United World College in Mostar. Dobra Kniga.

Anderson, B. (2006). Imagined communities: Reflections on the origin and spread of nationalism. Verso books. (Original work published 1983)

Andjelic, N. (2003). Bosnia-Herzegovina: The end of a legacy. Psychology Press.

Aquilué, I, \& Roca, E. (2016). Urban development after the Bosnian War: The division of Sarajevo's territory and the construction of East Sarajevo. Cities, 58(2016), 152-163. https://doi.org/10.1016/j.cities.2016.05.008.

Association for Societies in Transition. (2021). Skatepark Sarajevo 2025. https://asstinstitute.net/skate-park-sarajevo-2025/

Basic, G., Delić, Z., \& Sofradzija, H. (2019). Ideology of neo-fascism, education, and culture of peace: the empirical case of Bosnia and Herzegovina. Critical Education, 10(6), 1-20.

Belloni, R. \& Deane, S. (2005). From Belfast to Bosnia: Piecemeal peacemaking and the role of institutional learning. Civil Wars, 7(3), 219-43.

Belyaeva N. (2017). Citizen plenums in Bosnia protests: Creating a post-ethnic identity. In E. Arbatli and D. Rosenberg (Eds.), Non-Western social movements and participatory 
democracy: Protest in the age of transnationalism (pp. 115-138). Springer. https://doi.org/10.1007/978-3-319-51454-3_8

Betonlandschaften. (2021). Skatepark, Kigali, Rwanda. https://www.betonlandschaften.de/en/portfolios/skatepark-kigali-ruanda-afrika/

Blokker P. (2005). Post-communist modernization, transition studies, and diversity in Europe. European Journal of Social Theory, 8(4), 503-525.

Brumann, C. (2018). Anthropological utopia, closet eurocentrism, and culture chaos in the UNESCO World Heritage Arena. Anthropological Quarterly, 91(4), 1203-1233. https://muse.jhu.edu/article/717026/pdf?casa_token=HIYbYI_W7_UAAAAA:pfNZomZ WjLVqW931KkiK48XGgfSmKj8ty4E0vafb7c4jjXvJJOhTC2K9KUyvtSHg2v61Wj2JCw

Carabelli, G. (2018). The divided city and the grassroots: the (un)making of ethnic divisions in Mostar. Palgrave Macmillan. https://doi.org/10.1007/978-981-10-7778-4

Crocker, C. (2007). The place of grand strategy, statecraft, and power in conflict management. In P. Aall, F. Hampson, \& C. Crocker (Eds.), Leashing the dogs of war (pp. 355-368). US Institute of Peace.

Easterling, K. (2014). Extrastatecraft: The power of infrastructure space. Verso Books.

Easterling, K. (2021). Medium design: Knowing how to work on the world. Verso Books.

Emkic E. (2018). Reconciliation and education in Bosnia and Herzegovina: From segregation to sustainable peace. Springer. https://doi.org/10.1007/978-3-319-73034-9_5

Forde, S. (2016). The bridge on the Neretva: Stari Most as a stage of memory in post-conflict Mostar, Bosnia-Herzegovina. Cooperation and Conflict, 51(4), 467-483.

Gans-Morse, J. (2004). Searching for transitologists: Contemporary theories of post-communist transitions and the myth of a dominant paradigm. Post-Soviet Affairs, 20(4), 320-349.

Greiff, T., \& Greiff, J. (2014). The "Need for success": Untying international peace interventions in Mostar. Alternatives, 39(2), 108-123. https://doi.org/10.1177/0304375414566153

Halilovic-Pastuovic, M. (2020). Bosnian post-refugee transnationalism: After the Dayton Peace Agreement. Springer. https://doi.org/ 10.1007/978-3-030-39564-3_4

Hill, M. (2018). Assembling the historic city: Actor networks, heritage mediation, and the return of the colonial past in post-Soviet Cuba. Anthropological Quarterly, 91(4), 1235+. https://link.gale.com/apps/doc/A573714356/PPCM?u=wint47629\&sid=bookmark -PPCM\&xid=be2bdf79

Horvath, A. (2021). Political alchemy: Technology unbounded. Routledge. https://doi.org/10.4324/9781003019183

Horvath, A. \& Szakolczai, A. (2018). Political anthropology. In S. Turner \& W. Outhwaite (Eds.), Sage Handbook of Political Sociology (pp. 189-204). Sage.

Kapidžić, D. (2020). Subnational competitive authoritarianism and power-sharing in Bosnia and Herzegovina. Southeast European and Black Sea Studies, 20(1), 81-101. https://doi.org/10.1080/14683857.2020.1700880

Kappler, S. (2017). Sarajevo's ambivalent memoryscape: Spatial stories of peace and conflict. Memory Studies, 10(2), 130-143. https://doi.org/10.1177/1750698016650484

Kurtović, L. (2018). Conjuring "the people". Focaal: Journal of Global and Historical Anthropology, 2018(80), 43-62. https://doi.org/10.3167/fcl.2018.800104

Lai, D. (2020). Socioeconomic justice: International intervention and transition in post-war Bosnia and Herzegovina. Cambridge University Press. https://doi.org/10.1080/09668136.2021.1912927 
Lippman, P. (2019). Surviving the peace: The struggle for postwar recovery in BosniaHerzegovina. Vanderbilt University Press.

Maksić, A. (2017). Ethnic mobilization, violence, and the politics of affect: The Serb Democratic Party and the Bosnian War. Springer. https://doi.org/10.1007/978-3-319-48293-4

Mihaylov, G. (2020). Ethnoterritorial divisions and urban geopolitics in Post-Yugoslav Mostar. In V. Mihaylov (Ed.), Spatial conflicts and divisions in post-socialist cities. Springer. https://doi.org/10.1007/978-3-030-61765-3_6

Milan C. (2017). Reshaping citizenship through collective action: Performative and prefigurative practices in the 2013-2014 cycle of contention in Bosnia \& Hercegovina. Europe-Asia Studies, 69(9), 1346-1361. https://doi.org/10.1080/09668136.2017.1388358

Milan, C. (2019). Social mobilization beyond ethnicity: Civic activism and grassroots movements in Bosnia and Herzegovina. Routledge. https://doi.org/10.4324/9781351174244

Mohamedou, M. \& Sisk, T. (2017). Democratisation in the $21^{\text {st }}$ century: Reviving Transitology. Taylor and Francis. https://doi.org/10.4324/9781315561677

Morrison, K. (2016). Sarajevo's Holiday Inn on the frontline of politics and war. Palgrave Macmillan.

Mujanović, J. (2018). Hunger and Fury: The Crisis of democracy in the Balkans. Oxford University Press.

Mujkić, A. \& Hulsey, J. (2010). Explaining the success of nationalist parties in Bosnia and Herzegovina. Politicka Misso, 47(2), 143-156.

Norris, P. (2008). Driving democracy: Do power-sharing institutions work? Cambridge University Press. https://doi.org/10.1017/CBO9780511790614

Omaljev, A. (2016). Discourses on identity in 'First' and 'Other' Serbia: Social construction of the Self and the Other in a divided Serbia. Ibidem Press.

Organization for Security and Cooperation in Europe. Mission to Bosnia and Herzegovina. (2018). Two schools under one roof: The most visible example of discrimination in education in Bosnia and Herzegovina. November. https://www.osce.org/files/f/documents/3/8/404990.pdf

Osler A., \& Pandur, I. (2019). The right to intercultural education: students' perspectives on schooling and opportunities for reconciliation through multicultural engagement in Bosnia and Herzegovina. Intercultural Education, 30(6), 658-679. https://doi.org/10.1080/14675986.2019.1626576

Piacentini, A. (2018). The Weight of ethnic collectivism: Youth, identifications, and boundaries in post-conflict Bosnia Herzegovina. Studies in Ethnicity and Nationalism, 18(3), 262280. https://doi.org/10.1111/sena.12282.

Pobric, A. \& Robinson, G. (2019). Recent urban development and gentrification in post-Dayton Sarajevo, Bosnia and Herzegovina. Cities, 89(2019), 281-295. https://doi.org/10.1016/j.cities.2019.03.001.

Sarajlić, E. (2010). Bosnian elections and recurring ethnonationalisms: The ghost of the nation state. Journal on Ethnopolitics and Minority Issues in Europe, 9(2), 66-88.

Silverman, H. (2020). The Inca in the Plaza: debating change in the World Heritage historic urban centre of Cusco, Peru. International Journal of Heritage Studies, 26(11), 10921108.https://doi.org/10.1080/13527258.2020.1746921

Slessor, C. (2019, July 21). How to spot an architectural carbuncle. The Guardian: US Edition. https://www.theguardian.com/artanddesign/2019/jul/21/how-to-spot-an-architecturalcarbuncle 
Swimelar, S. (2020). LGBT rights in Bosnia: The challenge of nationalism in the context of Europeanization. Nationalities https://doi.org/10.1017/nps.2019.65

Szakolczai, A. (2009). Reflexive historical sociology. Routledge. https://doi.org/10.4324/9780203193617 Papers, 48(4), 768-790. czai, Á. (2017). Permanent (trickster) liminality: The reasons of the heart and of the mind. Theory \& Psychology, 27(2), 231-248. https://doi.org/10.1177/0959354317694095

Telesković, D. (2020, January 23). The great interview with Milan Kucan: Thirty years after the $14^{\text {th }}$ Congress. Nedeljnik. https://www.nedeljnik.rs/mi-smo-znali-da-skj-ne-shvatamo-kaosvoju-ako-ne-prihvate-nase-predloge-hrvati-nisu-imali-tu-pripremu-velika-ispovestmilana-kucana-30-godina-posle-cetrnaestog-kongresa/

Tellidis, I., \& Glomm, A. (2019). Street art as everyday counterterrorism? The Norwegian art community's reaction to the 22 July 2011 attacks. Cooperation and Conflict, 54(2), 191210.

Tešan, J. (2017). Defending the nation from her nationalism(s). Nationalism and Ethnic Politics, 23(1), 81-97.

Tešan, J. \& Davison, J. (2020). Leadership amidst transition and liminality: The case of Bosnia and Herzegovina and the former Yugoslavia. Advances in Politics and Economics 3(2), 16-34.

Thomassen, B. (2008). Mimetic errors in liminal schismogenesis: On the political anthropology of the trickster. International Political Anthropology, 1(1), 3-24.

Thomassen, B. (2012). Revisiting liminality: The danger of empty spaces. In H. Andrews \& L. Roberts (Eds.), Liminal landscapes: Travel, experience and spaces in-between (pp. 21-35). Routledge. https://doi.org/10.4324/9780203123164

Thomassen, B. (2014). Liminality and the modern: Living through the in-between. Routledge.

Todorova, M. (1997). Imagining the Balkans. Oxford University Press.

Tolomelli, A. (2015). "Two schools under one roof". The role of education in the reconciliation process in Bosnia and Herzegovina. Journal of Theories and Research in Education, 10(1), 89-108. https://doi.org/10.6092/issn.1970-2221/4685

UWC Mostar (2016). Who we are. https://uwcmostar.ba/who-we-are/

Van Gennep, A. (2019). The rites of passage. University of Chicago Press. (Original work published 1960)

Wollentz, G. (2017). Making a home in Mostar: Heritage and the temporalities of belonging. International Journal of Heritage Studies, 23(10). 928-945 https://doi.org/10.1080/13527258.2017.1347891

Wollentz, G. (2019). Conflicted memorials and the need to look forward. The interplay between remembering and forgetting in Mostar and on the Kosovo Field. In M. Sørensen, D. ViejoRose, \& P. Filippucci (Eds.), Memorials in the aftermath of armed conflict (pp. 159-182). Palgrave Macmillan. https://doi.org/10.1007/978-3-030-18091-1_61-97.

Woods, L. (1992). Anarchitecture: Architecture is a political act. Academy Press.

Woods, L. (1993). Pamphlet architecture 15: War and architecture (No. 15). Princeton Architectural Press. https://lebbeuswoods.wordpress.com/2011/12/15/war-andarchitecture-three-principles/

Woods, L. (2001). Radical reconstruction. Princeton Architectural Press.

Woods, L. (2011). War and architecture: Three principles. Word Press. https://lebbeuswoods.wordpress.com/2011/12/02/war-and-architecture-the-sarajevowindow/ 


\section{Notes on Contributors}

Joan Davison is Professor of Political Science. Her research focuses upon democratization in multi-ethnic societies. She recently edited Walling, boundaries and liminality: A political anthropology of transformations (Routledge, 2018) with Agnese Horvath and Marius Bentza.

Jesenko Tešan's dissertation at the University of Ireland examined the political and socioanthropological aspects of post-war instruments for conflict resolution. He currently is engaged in post-doctoral research on architectural design and permanent liminality. 